\title{
STUDIES ON THE CHEMOTHERAPY OF THE HUMAN MALARIAS. $X$. THE SUPPRESSIVE ANTIMALARIAL EFFECT OF PALUDRINE ${ }^{1,2}$
}

\author{
BY DAVID P. EARLE, JR., ROBERT W. BERLINER, JOHN V. TAGGART, CHARLES \\ G. ZUBROD, ${ }^{3}$ WILLIAM J. WELCH, ${ }^{3}$ FREDERICK S. BIGELOW, ${ }^{3}$ \\ THOMAS J. KENNEDY, JR., 3 AND JAMES A. SHANNON \\ (From the Department of Medicine, New York University College of Medicine, and the \\ Research Service, Third [New York University] Medical Division, \\ Goldwater Memorial Hospital, New York City)
}

(Received for publication March 12, 1947)

Paludrine, $\mathrm{N}_{1}$-p-chlorphenyl- $\mathrm{N}_{5}$-isopropylbiguanide acetate, was found by British workers to be the most active antimalarial of a series of synthetic guanidines and biguanidines $(1,2)$. It possesses high activity against the erythrocytic asexual parasites of both vivax and falciparum malaria and is practically non-toxic at therapeutic doses $(3,4)$. Previous study of the compound has included extensive prophylactic, curative and suppressive trials by the Australian Malarial Unit at Cairns in experimental sporozoite and trophozoite induced vivax and falciparum malaria (5) and curative trials in naturally acquired relapsing Southwest Pacific vivax malaria (6). The drug has a prophylactic action in falciparum malaria which is complete in single doses as low as 25 $\mathrm{mgm}$. The prophylactic action in vivax malaria is less definite, although the incubation periods of patients in the Cairns studies were systematically prolonged, and subinoculations from infected patients showed that this was due to an effect upon the initial tissue phase ( $c f .7)$ of the disease. It is also effective in the treatment of clinical attacks of malaria, being curative in falciparum but not in vivax malaria. The response of fever and symptoms in each infection is somewhat less prompt

1 The work described in this paper was done under a contract, recommended by the Committee on Medical Research, between the Office of Scientific Research and Development and New York University.

2 The authors express their thanks to the Malaria Study Section of the National Institute of Health for editorial assistance and for arrangements in regard to the publication of this paper. They are also grateful to the Abbott Laboratories, E. I. du Pont de Nemours and Company, Inc., E. R. Squibb and Sons, Eli Lilly and Company, Sharp and Dohme, and Wyeth, Inc., for contributing toward the publication costs.

3 Captain, MC, AUS. than that obtained with high dosage of quinacrine or chloroquine (8).

The present paper is a report on the assay of the suppressive antimalarial activity of paludrine in standardized blood-induced malarial infections. The studies were designed to yield comparative data on the suppressive antimalarial activity of paludrine and other antimalarials now coming into general use.

\section{MATERIALS AND METHODS}

The therapeutic trials were performed in patients 4 with blood-induced malaria in accordance with standard procedures previously outlined $(7,9)$. The infections utilized were due to the McCoy and Chesson strains of $P$. vivax and a relatively quinine-resistant strain of $P$. falciparum (Costa). The therapeutic results due to the administration of paludrine are classified in three groups: Class I, no certain effect; Class II, temporary suppression of parasitemia and/or fever; and Class III, a "permanent" effect, i.e., absence of parasitemia for 14 days in McCoy vivax, or 21 days in Chesson vivax and Costa falciparum, followed by a positive reinoculation to demonstrate continuing host-susceptibility to the infection.

Paludrine ${ }^{5}$ was administered by mouth in each instance, and all doses are reported in terms of the free base. Plasma paludrine levels ${ }^{6}$ were estimated by a method that involves coupling of the compound with methyl orange to yield an organic-soluble colored complex (10). The method permits the valid estimation of

4 Many of the subjects in this investigation were volunteers from the United States Disciplinary Barracks, Green Haven, New York. The authors express their appreciation to Colonel George Schulz, Lieut. Colonel Nathan Freeman, and Lieut. Colonel Michael D. Buscemi, whose assistance made this work possible.

5 Paludrine was generously furnished by The Imperial Chemical Industries, Ltd.

${ }^{6}$ In many instances, especially, at the lower doses, when only one to four individual doses were used, a stable plasma drug level could not be maintained for the usual four or six days. 
plasma paludrine levels as low as $10 \mu \mathrm{g}$. per liter. However, considerably lower plasma paludrine concentrations resulted from some of the dosage regimens examined; these were not estimated. A more sensitive chemical method is now available (11).

\section{RESULTS}

Paludrine in varying dosage was administered to 28 white subjects with blood-induced McCoy strain vivax malaria (Table I). It was soon apparent that the drug is extremely effective against the erythrocytic phase of this strain of malaria. A permanent eradication of parasites, or Class III effect, was noted in all patients with a four-day mean plasma paludrine concentration of 10 or more $\mu \mathrm{g}$. per liter. Total doses of paludrine as low as $50 \mathrm{mgm}$. were sufficient to produce Class III effects with regularity. The lowest total dose investigated, $12.5 \mathrm{mgm}$., was given to ten patients. Even this minute amount of drug had a dramatic effect on the course of the disease, Class III effects being noted in three instances, while complete

TABLE I

The relationship between dosage and plasma concentration of paludrine and therapertic effect in four-day tests against blood-induced $M c$ Coy vivax malaria

\begin{tabular}{|c|c|c|c|c|}
\hline \multirow{2}{*}{ Patient } & \multirow{2}{*}{$\begin{array}{l}\text { Total } \\
\text { dose }\end{array}$} & \multirow{2}{*}{$\begin{array}{c}\text { Mean } \\
\text { plasma } \\
\text { paludrine } \\
\text { concen- } \\
\text { tration }\end{array}$} & \multicolumn{2}{|c|}{ Class of therapeutic effect } \\
\hline & & & II & III \\
\hline $\begin{array}{l}\text { Bro } \\
\text { Con } \\
\text { Wit } \\
\text { Pow } \\
\text { Tay } \\
\text { Che } \\
\text { Bur } \\
\text { Jor } \\
\text { Sou } \\
\text { Fla } \\
\text { Ham } \\
\text { O'Br } \\
\text { Qui } \\
\text { Mor } \\
\text { Mar } \\
\text { Kli } \\
\text { Cha } \\
\text { Ott } \\
\text { Tha } \\
\text { Fit } \\
\text { McL } \\
\text { Dic } \\
\text { Pur } \\
\text { Lev } \\
\text { Spe } \\
\text { McI } \\
\text { Bre } \\
\text { Moo }\end{array}$ & $\begin{array}{c}\text { mgm. } \\
225 \\
225 \\
238 \\
150 \\
150 \\
150 \\
225 \\
150 \\
150 \\
100 \\
50 \\
50 \\
100 \\
50 \\
100 \\
25 \\
25 \\
25 \\
12.5 \\
12.5 \\
12.5 \\
12.5 \\
12.5 \\
12.5 \\
12.5 \\
12.5 \\
12.5 \\
12.5\end{array}$ & $\begin{array}{c}\text { Mg./L } \\
56 \\
51 \\
48 \\
38 \\
30 \\
29 \\
23 \\
22 \\
22 \\
21 \\
20 \\
17 \\
17 \\
13 \\
10 \\
- \\
- \\
- \\
- \\
- \\
- \\
- \\
- \\
- \\
- \\
-\end{array}$ & $\begin{array}{l}\mathbf{x} \\
\mathbf{x} \\
\mathbf{x} \\
\mathbf{x} \\
\mathbf{x} \\
\mathbf{x} \\
\mathbf{x} \\
\mathbf{x} \\
\mathbf{x} \\
\mathbf{x}\end{array}$ & $\begin{array}{l}\mathbf{x} \\
\mathbf{x} \\
\mathbf{x} \\
\mathbf{x} \\
\mathbf{x} \\
\mathbf{x} \\
\mathbf{x} \\
\mathbf{x} \\
\mathbf{x} \\
\mathbf{x} \\
\mathbf{x} \\
\mathbf{x} \\
\mathbf{x} \\
\mathbf{x} \\
\mathbf{x}\end{array}$ \\
\hline
\end{tabular}

TABLE II

The relationship between dosage and plasma concentration of paludrine and therapeutic effect in four-day tests against blood-induced Chesson vivax malaria

\begin{tabular}{|c|c|c|c|c|}
\hline \multirow{2}{*}{ Patient } & \multirow{2}{*}{$\begin{array}{l}\text { Total } \\
\text { dose }\end{array}$} & \multirow{2}{*}{$\begin{array}{c}\text { Mean } \\
\text { plasma } \\
\text { paludrine } \\
\text { concen- } \\
\text { tration }\end{array}$} & \multicolumn{2}{|c|}{ Class of therapeutic effect } \\
\hline & & & II & III \\
\hline $\begin{array}{l}\text { Mer } \\
\text { Mur } \\
\text { O'Be } \\
\text { Mon } \\
\text { Lyo } \\
\text { Mur } \\
\text { Pet } \\
\text { Pad } \\
\text { Gol } \\
\text { You } \\
\text { Lem } \\
\text { Sca } \\
\text { Lev } \\
\text { Sny } \\
\text { Sig } \\
\text { Smi }\end{array}$ & $\begin{array}{r}m g m . \\
4000 \\
4000 \\
500 \\
500 \\
500 \\
225 \\
150 \\
150 \\
150 \\
225 \\
100 \\
100 \\
25 \\
25 \\
25 \\
25\end{array}$ & $\begin{array}{r}\mu g . / L \\
688 \\
464 \\
-70 \\
59 \\
49 \\
40 \\
34 \\
39 \\
28 \\
17 \\
- \\
- \\
- \\
- \\
-\end{array}$ & $\begin{array}{l}\mathbf{x} \\
\mathbf{x} \\
\mathbf{x}\end{array}$ & $\begin{array}{l}\mathbf{x} \\
\mathbf{x} \\
\mathbf{x} \\
\mathbf{x} \\
\mathbf{x} \\
\mathbf{x} \\
\mathbf{x} \\
\mathbf{x} \\
\mathbf{x} \\
\mathbf{x} \\
\mathbf{x}\end{array}$ \\
\hline
\end{tabular}

temporary, or Class II, effects occurred in the other seven patients.

The effect of paludrine against the Chesson strain of vivax malaria was examined in $16 \mathrm{pa}$ tients (Table II). This strain had previously been demonstrated to be more resistant than the McCoy strain of vivax to the suppressive antimalarial action of quinine, quinacrine, and chloroquine $(7,12,13)$. Total doses of $150 \mathrm{mgm}$. or more of paludrine resulted in Class III effects. One of two patients given a total dose of $100 \mathrm{mgm}$. had a Class III effect, the other, a Class II effect. At the lowest total dose studied, $25 \mathrm{mgm}$., two patients had Class III effects, and two had Class II effects. It is likely that paludrine is only slightly less effective against the Chesson strain than against the McCoy strain.

In contrast, the quinine-resistant Costa strain of falciparum malaria was also relatively resistant to the suppressive action of paludrine (Table III). Total doses ranging from 338 to $750 \mathrm{mgm}$. were administered to nine patients. The six-day mean plasma paludrine levels varied from 55 to $106 \mu \mathrm{g}$. per liter. Class III or permanent effects were noted in two patients with mean plasma drug levels of 78 and $95 \mu \mathrm{g}$. per liter, the remainder of the patients having Class II or complete temporary effects, the parasite-free intervals ranging from two to 14 days. 
TABLE III

The relationship between dosage and plasma concentration of paludrine and therapeutic effect in six-day tests against blood-induced Costa falciparum malaria

\begin{tabular}{|c|c|c|c|c|}
\hline \multirow{2}{*}{ Patient } & \multirow{2}{*}{$\begin{array}{l}\text { Total } \\
\text { dose }\end{array}$} & \multirow{2}{*}{$\begin{array}{c}\text { Mean } \\
\text { plasma } \\
\text { paludrine } \\
\text { concen- } \\
\text { tration }\end{array}$} & \multicolumn{2}{|c|}{ Class of therapeutic effect } \\
\hline & & & II & III \\
\hline $\begin{array}{l}\text { McC } \\
\text { O'Ne } \\
\text { Sca } \\
\text { Dav } \\
\text { Gib } \\
\text { Wil } \\
\text { Sha } \\
\text { Vel } \\
\text { Ros }\end{array}$ & $\begin{array}{c}m g m . \\
500 \\
750 \\
750 \\
750 \\
500 \\
550 \\
500 \\
338 \\
500\end{array}$ & $\begin{array}{r}\mu g . / L \\
106 \\
103 \\
102 \\
95 \\
82 \\
78 \\
74 \\
68 \\
55\end{array}$ & $\begin{array}{l}\mathbf{x} \\
\mathbf{x} \\
\mathbf{x} \\
\mathbf{x} \\
\mathbf{x} \\
\mathbf{x} \\
\mathbf{x}\end{array}$ & $\begin{array}{l}\mathbf{x} \\
\mathbf{x}\end{array}$ \\
\hline
\end{tabular}

In no instance of treatment with paludrine was an adverse side reaction noted that could be ascribed to the drug.

\section{DISCUSSION}

The doses and plasma drug levels of paludrine, quinacrine (12) and chloroquine (13) required to achieve Class III effects in McCoy and Chesson strain vivax malaria and Costa strain falciparum are summarized in Table IV.

It is apparent that paludrine has extraordinary effectiveness against the erythrocytic phase of vivax malaria. The peripheral trophozoites of two strains of vivax can be permanently eradicated with oral doses much smaller than are necessary with other antimalarials such as quinacrine or chloroquine. Permanent eradication of the peripheral trophozoites of Costa falciparum was not regularly achieved at the dosage tested. It should be noted, however, that the dosage used was far

TABLE IV

Total doses and mean plasma drug levels of paludrine, quinacrine and chloroquine required to achieve Class III effects in two strains of vivax malaria and one strain of falciparum malaria

\begin{tabular}{|c|c|c|c|c|c|c|}
\hline & \multicolumn{2}{|c|}{ Paludrine } & \multicolumn{2}{|c|}{ Quinacrine } & \multicolumn{2}{|c|}{ Chloroquine } \\
\hline & $\begin{array}{l}\text { Total } \\
\text { dose }\end{array}$ & $\begin{array}{c}\text { Plas- } \\
\text { ma } \\
\text { level }\end{array}$ & $\begin{array}{l}\text { Total } \\
\text { dose }\end{array}$ & $\begin{array}{c}\text { Plas- } \\
\text { ma } \\
\text { level }\end{array}$ & $\begin{array}{l}\text { Total } \\
\text { dose }\end{array}$ & $\begin{array}{c}\text { Plas- } \\
\text { ma } \\
\text { level }\end{array}$ \\
\hline $\begin{array}{l}\text { Vivax, McCoy strain } \\
\text { Vivax, Cheeson strain } \\
\text { Falciparum, Costa strain }\end{array}$ & $\begin{array}{r}m g m . \\
50 \\
150 \\
>750\end{array}$ & $\begin{array}{r}\mu g . / L \\
10^{*} \\
17^{*} \\
>100^{\circ}\end{array}$ & $\begin{array}{r}m g m_{0} \\
700 \\
1100 \\
>1100\end{array}$ & $\begin{array}{c}\mu g_{0} / L \\
25^{*} \\
25 \dagger \\
65 \dagger\end{array}$ & $\begin{array}{c}\text { mgm. } \\
300 \\
650\end{array}$ & $\begin{array}{l}\mu s . / L \\
10^{*} \\
30 t\end{array}$ \\
\hline
\end{tabular}

* 4 day mean plasma drug level.

† 6 day mean plasma drug level. below the toxic dose $(5,6)$ and the dose recommended for treatment of clinical attacks of malaria (6).

The study of paludrine was undertaken at too late a date in the malaria program to collect definitive data on the relation between oral dosage, plasma paludrine levels, and antimalarial effects in either vivax or falciparum malarias. As far as falciparum malaria was concerned, there was no apparent correlation between effect and drug levels in the range of 55 to $106 \mu \mathrm{g}$. per liter.

The observations upon which these summarizing statements are based do not define the potentialities of paludrine in the routine suppression and treatment of malaria. It seems likely that routine suppression in falciparum malaria is accomplished by a combination of the very high order of the drug's prophylactic action and the moderate order of its suppressive action; whereas, in vivax malaria, it is accomplished by the high order of its suppressive action, perhaps aided by a minor degree of prophylactic action. Routine treatment of the clinical attack will usually involve the administration of high dosage as compared to the dosage utilized in these studies. The effectiveness of such high dosage is best illustrated by the experimental work of others $(3,4,5,6)$.

The high order of antimalarial activity shown by paludrine against more than a single phase of the malarias, i.e., primary tissue phase of falciparum and erythrocytic phases of vivax and falciparum, places the drug in a unique position among the synthetic antimalarials developed in recent years.

\section{SUMMARY AND CONCLUSIONS}

1. Paludrine is the most active suppressive agent in vivax malaria yet described, exceeding quinacrine or chloroquine to a considerable extent in this respect.

2. It is less active as a suppressive in falciparum malaria, routine suppression at low dosage being due presumably to its high order of prophylactic action in this infection.

3. Paludrine is apparently non-toxic in therapeutic doses.

\section{BIBLIOGRAPHY}

1. Curd, F. H. S., Davey, D. G., and Rose, F. L., Studies on synthetic antimalarial drugs. $X$. Some biguanide derivatives as new type of antimalarial 
substances with both therapeutic and causal prophylactic activity. Ann. Trop. Med., 1945, 39, 208.

2. Curd, F. H. S., Davey, D. G., and Rose, F. L., Studies on synthetic antimalarial drugs. II. General chemical considerations. Ann Trop. Med., 1945, 39, 157.

3. Adams, A. R. D., Maegraith, B. B., King, J. D., Townshend, R. H., Davey, T. H., and Havard, R. E., Studies on synthetic antimalarial drugs. XII. Results of a preliminary investigation of the therapeutic action of 4888 (paludrine) on acute attacks of benign tertian malaria. Ann. Trop. Med., 1945, 39, 225.

4. Maegraith, B. G., Adams, A. R. D., King, J. D., Townshend, R. H., Davey, T. H., and Havard, R. E., Studies on synthetic antimalarial drugs. XIV. Results of a preliminary investigation of the therapeutic action of 4888 (paludrine) on acute attacks of malignant tertian malaria. Ann. Trop. Med., 1945, 39, 232.

5. Fairley, N. H., Researches on paludrine (M. 4888) in malaria. Tr. Roy. Soc. Trop. Med. \& Hyg., 1946, 40, 105.

6. Fairley, N. H., Researches on paludrine (M. 4888) in malaria. Appendix, Tr. Roy. Soc. Trop. Med. \& Hyg., 1946, 40, 152.

7. Shannon, J. A., Earle, D. P., Jr., Berliner, R. W., and Taggart, J. V., Studies on the chemotherapy of the human malarias. I. Method for the quantitative assay of suppressive antimalarial action in vivax malaria. J. Clin. Invest., 1948, 27, Suppl., 66.

8. Jones, R., Jr., Pullman, T. N., Whorton, C. M., Craige, B., Jr., Alving, A. S., and Eichelberger, L., The therapeutic effectiveness of large doses of paludrine in acute attacks of sporozoite-induced vivax malaria (Chesson strain). J. Clin. Invest., 1948, 27, Suppl., 51.

9. Earle, D. P., Jr., Berliner, R. W., Taggart, J. V., Welch, W. J., Zubrod, C. G., Wise, N. B., Chalmers, T. C., Greif, R. L., and Shannon, J. A., Studies on the chemotherapy of the human malarias. II. Method for the quantitative assay of suppressive antimalarial action in falciparum malaria. J. Clin. Invest., 1948, 27, Suppl., 75.

10. Brodie, B. B., Udenfriend, S., and Dill, W., The estimation of basic organic compounds in biological material. V. Estimation by salt formation with methyl orange. J. Biol. Chem., 1947, 168, 335.

11. Spinks, A., and Tottey, M. M., Studies on synthetic antimalarial drugs. XII. Determination of $\mathrm{N}_{1}$-p-chlorophenyl- $\mathrm{N}_{5}$-methyl- $\mathrm{N}_{5}$-isopropylbiguanide (4430) and $\mathrm{N}_{1}$-p-chlorophenyl- $\mathrm{N}_{6}$-isopropylbiguanide (paludrine): a preliminary report. Ann. Trop. Med., 1945, 39, 220.

12. Taggart, J. V., Earle, D. P., Jr., Berliner, R. W., Welch, W. J., Zubrod, C. G., Jailer, J. W., Kuhn, B. H., Norwood, J., and Shannon, J. A., Studies on the chemotherapy of the human malarias. V. The antimalarial activity of quinacrine. J. Clin. Invest., 1948, 27, Suppl., 93.

13. Berliner, R. W., Earle, D. P., Jr., Taggart, J. V., Zubrod, C. G., Welch, W. J., Conan, N., Bauman, E., Scudder, S. L., and Shannon, J. A., Studies on the chemotherapy of the human malarias. VI. The physiological disposition, antimalarial activity and toxicity of several derivatives of 4-aminoquinoline. J. Clin. Invest., 1948, 27, Suppl., 98. 